\title{
Perfeita civilização:
}

a transferência da corte,

a escravidão e o desejo

de metropolizar uma

capital colonial.

Rio de Janeiro, 1808-1821*

Kirsten Schult:**

Esse artigo desenvolve uma análise do processo ambivalente de transformação da capital colonial em corte real, verificado no final do período colonial no Brasil após a fuga da família real de Portugal para o Rio de Janeiro. Ao "metropolizar" a cidade, oficiais régios buscaram limitar a demonstração pública da presença da escravidão e redefinir as fronteiras físicas e sociais interpostas aos escravos africanos e afrodescendentes, contingente que somava cerca da metade do total da população da cidade. Esses esforços foram, entretanto, limitados pela intensificação do uso do trabalho escravo e o apego dos oficiais a certos ideais coloniais acerca dos melhores meios para assegurar a ordem na cidade.

Palavras-chave: Rio de Janeiro Joanino - Escravidão - Metropolização

*Artigo recebido em outubro de 2007 e aprovado para publicação em dezembro de 2007.

**A autora é professora da The Cooper Union. E-mail: schultz@cooper.edu. 
Perfect civilization: the transfer of the court, the slavery and the desire to metropolitanize a colonial capital. Rio de Janeiro, 1808-1821

This article provides an analysis of the ambivalent process of transforming a colonial capital into a royal court at the end of the colonial period in Brazil after the flight of the Portuguese royal family from Portugal to Rio de Janeiro. In "metropolitanizing" the city, royal officials sought to limit the public display of slavery and redefine physical and social boundaries for the African and African-Brazilian slaves who made up half of the population. These efforts were, however, themselves limited by an intensification of the use of slave labor and by officials' dedication to colonial ideals of how to ensure order.

Keywords: D. João's Rio de Janeiro - Slavery - Metropolitanization

Parfaite civilisation: le transfert de la cour, l'esclavage et la perspective de de faire une metrópole d'une capitale coloniale. Rio de Janeiro, 1808-1821 L'article étudie le processus ambigu de la transformation de la capitale coloniale dans une Cour roylae, qui a eu lieu à la fin de la période coloniale dans le Brésil après la fuite de la famille royale du Portugal vers le Rio de Janeiro. Dans le but de faire de la ville de Rio de Janeiro une "metrópole", les officiels royaux ont essayé de limiter la présence publique de l'esclavage et de rédéfinir les frontières physiques et sociales imposées aux esclaves africains et aux afro-descendants, qui étaient la moitié environ da la population de la ville. Ces essais pourtant ont été contrecarrés par l'intensification de l'emploi du travail esclave et par l'attachement de ces officiels à des idéaux coloniaux sur les meilleurs moyens de maintenir l'ordre dans la ville. Mots-clés: Rio de Janeiro Joanino - Esclavage - Metropolisation

A transferência da corte portuguesa para o Brasil desafiou as hierarquias culturais e econômicas do império, vigentes de longa data. O que os contemporâneos em ambos os lados do Atlântico chamaram de "antigo sistema colonial" parecia ter chegado ao fim quando os portos da colônia foram abertos ao comércio exterior e a família real e os funcionários da corte se estabeleceram no Rio de Janeiro, sendo a cidade então reconhecida como a nova "metrópole" da monarquia. Apesar das circunstâncias catastróficas que levaram a tais transformações, os exilados da corte portuguesa, somados aos habitantes da nova corte real, viram as mudanças como uma oportunidade de renovação política e moral da colônia. A América, eles argumentavam, seria o refúgio da política revolucionária, das impiedades e da decadência da Europa. Como reconheciam os exilados, os habitantes da colônia e os membros da corte naquela época, sustentar essa visão de renovação do Novo Mundo 
Perfeita civilização: a transferência da corte, a escravidão e o desejo de metropolizar uma capital colonial. Rio de Janeiro, 1808-1821

exigia reformas correspondentes. A grandeza de uma monarquia americana começaria com a grandeza de sua nova capital. Examino aqui esta reconstrução do Rio de Janeiro, após a chegada do príncipe regente, como foi expressa nos discursos e práticas do projeto emergente para transformar a cidade em "corte" da monarquia. ${ }^{1}$

De um lado, os membros da corte tentaram reconstruir o Rio de Janeiro baseados nas experiências da renovação urbana do século XVIII em Portugal e no Brasil, nas quais tanto a projeção de poder real absoluto quanto o estabelecimento de uma ordem ilustrada tinham servido como objetivos primários. De outro, mesmo à medida que as reformas que se seguiram à transferência da corte deram continuidade àquelas experiências anteriores, o que um cronista local da época descreveu como a "metamorfose política" do Rio, também se definiu como sendo um momento histórico específico no qual tal transformação ocorreu. ${ }^{2}$ Ao contrário de reformas anteriores de Lisboa ou do Rio, a construção de uma nova corte na América dependia de uma metropolização explícita da cidade. Em outras palavras, os membros da corte e os habitantes do Rio reconheceram que a transferência da corte enfraquecia a dicotomia de metrópole/colônia e, portanto, a transformação do Rio de Janeiro em uma corte real obrigatoriamente pressupunha uma marginalização da estética e das práticas que não conseguissem refletir esta mudança. Foi uma tarefa que antecipou o paradoxo da América Latina pós-independência. Não mais ser colônia significava abraçar um projeto colonial: "civilizar". No entanto, como também reconheciam os membros da corte, havia limites tanto à visão de metropolização e cortesania no Novo Mundo quanto às fronteiras espaciais e temporais correspondentes que eles procuravam definir dentro da cidade, limites esses produzidos por seu próprio compromisso para com a característica preeminente da sociedade e da economia coloniais: a escravidão africana.

A transformação do Rio de Janeiro em uma corte real começou dois meses antes da chegada do príncipe regente, quando foram recebidas as notícias do exílio real, tanto "lisonjeiras" e "gostosas" quanto chocantes. Enquanto os habitantes, como insistiam em afirmar os memorialistas, viam a perspectiva de a cidade servir como a nova residência real com felicidade e orgulho, hospedando o príncipe regente, a família real e os nobres exilados,

\footnotetext{
${ }^{1}$ Este artigo, com algumas modificações, é baseado em dados de Kirsten Schultz, Tropical Versailles: Empire, Monarchy and the Portuguese court in Rio de Janeiro, 1808-1821, Nova York, Routledge, 2001.

${ }^{2}$ Luiz Gonçalves dos Santos, Memórias para servir à história do reino do Brasil, t. 1 (1825), Belo Horizonte/São Paulo, Itatiaia/EDUSP, 1981, p. 335.
} 
era esta, no entanto, uma tarefa assustadora, que exigia mobilização em larga escala, bem como despesas extraordinárias. Os preparativos foram iniciados imediatamente. Para dar alojamento apropriado ao príncipe regente, o palácio vice-real foi ampliado, com a anexação da cadeia adjacente, a parte externa do palácio foi pintada e as paredes do interior foram cobertas de seda, as igrejas da cidade foram limpas e um dossel do melhor tecido foi erguido perto do cais. Como conseqüência disso, ao ver a elite da cidade receber o príncipe regente e sua comitiva entre decorações de luxo e iluminação festiva, um habitante da cidade escreveu: "parecia o Rio de Janeiro huma nova Cidade". 3

No entanto, como os habitantes da cidade descobriram as preparações iniciais para hospedar D. João e os exilados marcou apenas o começo do processo de transformação do Rio de Janeiro, já que o projeto de construir uma nova cidade e capital imperial perdurou durante todo o reinado do príncipe regente no Brasil. À medida que a população da cidade crescia (dobrando para 80 mil entre 1808 e 1821) e o comércio de varejo aumentava, membros da corte recém-chegados construíram casas e propriedades e a Coroa subvencionava a construção de novos prédios públicos, bem como um palácio maior para o príncipe regente em São Cristóvão. Uma Imprensa Real foi instituída pela primeira vez na história da colonização portuguesa no Brasil, e novas academias reais, uma escola de medicina, a biblioteca real e aulas régias ampliadas ofereciam novas oportunidades de educação e de treinamento profissional. A duplicação de instituições, incluindo o Desembargo do Paço, a Casa de Suplicação do Brasil, a Junta de Comércio e o Erário Real, assim como a criação de um Banco do Brasil, trouxe prestígio à cidade, facilitou a administração e o exercício da justiça e de transações econômicas, proporcionando oportunidades para a prestação de serviços à corte real. ${ }^{4}$

\footnotetext{
${ }_{3}^{3}$ Sobre a recepção, ver Gonçalves dos Santos, Memórias, t. 1, p. 167-187; Relação das Festas que se Fizerão no Rio de Janeiro quando o Principe Regente N.S. e toda a sua familia chegarão pela primeira vez a'quella Capital (...), Lisboa, Impressão Régia, 1810, p. 4-6, 11-12; "Preparativos no Rio de Janeiro para receber a Família Real Portuguesa", 16 de janeiro de 1808, e relato da recepção de 23 de março de 1808, Biblioteca Nacional, Rio de Janeiro, Seção de Manuscritos (referido a partir daqui como BNRJ Ms.) II-35,4,1.

${ }^{4}$ Estimativas da população da cidade em 1821 são de 43.439 pessoas livres e 36.182 escravos, para um total de 79.321. Veja Joaquim José de Queirós, "Mappa da população da Côrte e provincia do Rio de Janeiro em 1821", Revista do Instituto Historico e Geografico Brasileiro 33, pt.1 (1870). Sobre a economia e a sociedade do Rio de Janeiro no final do século XVIII e início do século XIX, ver João Fragoso e Manolo Florentino, O Arcaísmo como Projeto: Mercado Atlantico, Sociedade Agrária e Elite Mercantile no Rio de Janeiro, c.1790-c.1840, Rio de Janeiro, Diadorim, 1993. Sobre as transformações urbanas após a chegada da corte, ver Alan K. Manchester, "The Transfer of the Portuguese Court to Rio de Janeiro", em Henry H. Keith e S. F. Edwards, eds., Conflict and Continuity in Brazilian Society, Columbia, University of South Carolina Press, 1969, p. 169-170; e Paulo César Garcez Marins, Através da rótula: sociedade e arquitectura urbana no Brasil, séculos XVII a XX, São Paulo, Humanitas/FFLCH/USP, 2001, capítulo 4.
} 
Ao que os funcionários da corte se referiam como a "perfeição" da cidade também significava a criação e manutenção de uma uniformidade estética e cultural, bem como a redefinição de regras próprias para a conduta pública que refletia hierarquia, virtude e esplendor real. Para assegurar o decoro exigido das aparições cerimoniais do príncipe, um funcionário real foi designado para instruir e resolver questões relacionadas com o uso, por parte dos habitantes da cidade, de insígnias e dos procedimentos adequados a desfiles públicos. ${ }^{5}$ A "velha vestimenta da corte era exigida", relatava o britânico John Luccock, residente na cidade, e aqueles a quem ele denominava de "a pequena nobreza local" ficaram mais atentos à propriedade e ao bom gosto em seus modos de vestir". No entanto, como Lucock também observou, não era uma ausência de boas maneiras e deferência na elite colonial que o novo decoro da corte suplantou, mas sim uma severidade e austeridade que evocava o isolamento provinciano, ao invés da vida dinâmica de uma residência real. A "formalidade que tinha prevalecido até então nas maneiras da Cidade”, explicou Luccock, dera lugar a "um ar de alvoroço e importância". O Rio de Janeiro tornou-se, de acordo com a sua descrição, "um lugar pomposo e fofoqueiro". ${ }^{6}$

Depois do fim das Guerras Napoleônicas, quando o fervoroso patriotismo antifrancês começou a arrefecer, a corte portuguesa e a elite da cidade também começaram a se inspirar na França, como já tinham feito em Lisboa, a fim de encontrar modelos de refinamento estético para a nova corte. De fato, em 1815 a Coroa agiu a fim de consolidar a elegância cosmopolita e o crescente esplendor do Rio de Janeiro, recrutando e subsidiando um certo número de artistas franceses. O Brasil, como explicava o decreto que formalmente anunciava essas intenções, "precisa de grandes socorros da estética para aproveitar os produtos, cujo valor e preciosidade podem vir a formar o Brasil como o mais rico e opulento dos Reinos conhecidos”. O que veio a ser conhecida como a Missão Cultural Francesa incluía mais de uma dúzia de artistas e artesãos: pintores, escultores, gravadores, um compositor, um engenheiro e um arquiteto. Como os historiadores têm observado, a assim chamada missão rendeu seus frutos mais adiante na história brasileira, com

\footnotetext{
${ }^{5}$ Arnold B. Clayton, "The Life of Tomás Antônio Vilanova Portugal: A Study in the Government of Portugal and Brazil", Tese de doutorado, Columbia University, 1977, p. 84; Jurandir Malerba, A corte no exílio: civilização e poder no Brasil às vesperas da Independência (1808 a 1821), São Paulo, Companhia das Letras, 2000, capítulos 1 e 3.

${ }^{6}$ John Luccock, Notes on Rio de Janeiro and the southern parts of Brawil; taken during a Residence of 10 years in that country, from 1808-1818, Londres, Samuel Leigh, 1820, p. $245-246,254,548$.
} 
a criação de um museu nacional e de uma escola nacional de belas artes nos anos 1830. Todavia, durante o reinado no Brasil de D. João VI, esses artistas e artesãos franceses deram à Coroa uma visão de civilização, progresso e ordem, inspirada pelo neoclassicismo francês. ${ }^{7}$

Essa criação de cortesania em uma antiga capital colonial foi também definida como a garantia do bem-estar dos habitantes da cidade e a "segurança pessoal e tranquilidade" dos "fiéis vassalos" do príncipe regente. Assim, de um lado, uma Intendência Geral de Polícia, criada depois da chegada do príncipe regente ao Rio, promovia "o bem comum", procurando assegurar o suprimento de gêneros alimentícios e iniciando projetos para criar calçadas, aterros, iluminação pública, novos reservatórios de água públicos, um sistema de esgotos eficiente e mais estradas e pontes. De outro, o intendente, o magistrado do Rio, treinado em Coimbra (Paulo Fernandes Viana), coordenou o primeiro esforço sistemático para coibir a criminalidade no Brasil. "Com ampla e ilimitada jurisdição", a intendência juntou esforços policiais, antes limitados e incompatíveis, sob a liderança de um desembargador, com poderes legislativos, executivos e judiciários. Para acabar com a desordem pública e com o crime dentro da cidade, o intendente também tinha à sua disposição a divisão militar da guarda real da polícia, criada em 1809. Suas quatro companhias, distribuídas por toda a cidade, faziam rondas noturnas, dispersavam ajuntamentos após o pôr do sol, verificavam que os cafés e as casas de jogos fechavam nos seus respectivos horários, e prendiam qualquer suspeito de vadiagem e de atividade criminosa. ${ }^{8}$

\footnotetext{
${ }^{7} \mathrm{O}$ decreto é citado em Afonso de E. Taunay, A missão artística de 1816, Rio de Janeiro, Diretoria do Patrimônio Histórico e Artístico Nacional, 1956, p. 18. Para exemplos do estilo neoclássico no Rio de Janeiro, ver Jean Baptiste Debret, Viagem pitoresca e histórica ao Brasil (1834) t. 3, Belo Horizonte/São Paulo: Itatiaia/Edusp, 1989, prancha 41; Clarival do Prado Valladares, Rio: análise iconográfica do Barroco e Neoclássico remanentes no Rio de Janeiro, v. 2, Rio de Janeiro, Bloch, 1978; e Uma cidade em questão I: Grandjean de Montigny e o Rio de Janeiro, Rio de Janeiro: PUC, 1978.

8 "Alvará, porque Vossa Alteza Real he Servido Crear no Estado do Brasil hum Intendente Geral da Polícia, na forma acima declarada (...)", 10 de maio de 1808, Rio de Janeiro, Impressão Régia, 1808; "Decreto", 13 de maio 1809, Rio de Janeiro, Impressão Régia, 1809; Rodrigo de Souza Coutinho, "Composição, e Regulação da Divizão Militar da Guarda Real da Polícia do Rio de Janeiro", 13 de maio de 1809, Rio de Janeiro, Impressão Régia, 1809, p. 7. O decreto criando a Intendência em Portugal é reproduzido em Mello Barreto Filho e Hermeto Lima, História da polícia do Rio de Janeiro. Aspectos da cidade e da vida carioca, 1565-1831 v. 1, Rio de Janeiro, S.A.A., Noite, s.d., 1939, p. 165-179. Sobre o policiamento em Portugal e no Brasil, ver José Subtil, "Os poderes do centro: governo e administração", em António Manuel Hespanha, coord., História de Portugal, v. 4, Lisboa, Estampa, p. 174-176; Thomas H. Holloway, Policing Rio de Janeiro: Repression and Resistance in a Nineteenth-Century City, Stanford, Stanford University Press, 1993, p. 28-33; e Maria Beatriz Nizza da Silva, “A Intendência-Geral da Polícia: 1808-1821", Acervo 1, n. 2, (Jul-Dez. 1986), p. 187-204. A jurisdição do Intendente abrangia todos os crimes relacionados aos corregedores e juizes do crime dos bairros e permitia ao intendente agir sumariamente nos casos ou enviá-los para a casa de suplicação quando necessário. Antes de 1808, nas cidades brasileiras a obrigação de manter e restaurar a paz era confiada a uma variedade de funcionários ad hoc: guardas civis contratados pelo senado da câmara, quadrilheiros designados por juízes locais e pelo conselho da cidade e, em alguns casos de grandes perturbações, ordenanças.
} 
No entanto, de acordo com Viana, os perigos e dilemas morais de se construir uma nova corte real também exigiam o reconhecimento de que uma "boa polícia" não se limitava à sanção de uma série de proibições e punições. O esplendor de uma corte real, com sua população ampliada, novos prédios públicos e locais de diversão, deveria ser conciliado tanto com segurança quanto com virtude, ele argumentou, dando-se uma "Educação moral" aos habitantes da cidade. Essa responsabilidade, como explica José Subtil, tinha sido uma característica central e, de certo modo, inovadora da instituição da intendência, desde sua criação em Portugal no contexto das reformas ilustradas do Marquês de Pombal. Para criar o que os contemporâneos chamaram de "vassalos úteis", Viana aconselhou a Coroa a direcionar atenção específica e força moral à população livre urbana pobre. Se o príncipe regente desse uma "educação" para aqueles que tinham seguido a estrada da "perdição" devido à sua "pobreza, e falta de meios", sugeriu Viana, ele iria se beneficiar de "vasallos de todas as cores". ${ }^{9}$ Mais especificamente, o intendente recomendava que a Coroa intensificasse esforços para assegurar que as classes inferiores livres se dedicassem a certas atividades produtivas. "Rapazes pobres", incluindo "mulatos, mestiços e pretos", eram presos e trazidos para a intendência "para serem empregados nas Fabricas onde serão por ora vestidos, e sustentados e para diante irão vencendo conforme o seo merecimento". ${ }^{10}$ Os presos, por sua vez, eram condenados a prestar serviços públicos, enquanto que os acusados de vadiagem ou de levarem uma vida desprovida de retidão moral, se estivessem na cidade e nas regiões vizinhas, eram sujeitos a uma "correção" que consistia na prestação de serviço real no exército, na milícia ou em outras atividades consideradas "a benefício do Estado". ${ }^{11}$

\footnotetext{
9 José Subtil, "Os poderes do centro", 176; Kenneth Maxwell, Pombal: Paradox of the Enlightenment, Nova York, Cambridge University Press, 1995, p. 88; Gonçalves dos Santos, Memórias t. 1, p. 273; Viana, Representação, 24 de novembro de 1816, f11, Arquivo Nacional, Rio de Janeiro, Ministério dos Negócios do Brasil (referido a partir daqui como ANJR MNB), caixa 6J 83. ${ }^{10}$ Viana, "Registro do Ofício expedido ao Juiz do Crime de São José", June 19, 1811, ANRJ, Códice 329 , v. 1 , f61.

${ }^{11}$ Viana, "Registro do Ofício expedido ao Comandante do Districto de Macacú", May 9, 1809, ANRJ, Códice 323, v. 1, f42v-43v; Viana, Informe, 17 de novembro de 1810, ANRJ MNB, caixa 6J 78; Viana para Vila Nova Portugal, 3 de setembro de 1820, ANRJ, Códice 323, v. 6, f20v. No registro de 1809, Viana também identificava uma série de categorias a serem visadas para "correção" e especificava que a reunião não deveria ser interpretada como recrutamento: 1. "Homem solteiro vadio que não se ocupa na lavoura que não seja filho unico de alguma viuva"; 2. "Homem solteiro ainda que seja filho unico mas no estado de valentão, briguento, e de outra qual quer mácula na Sociedade"; 3. "Homem Cazado que viva amancebado, e tenha largado sua mulher e filhos (...)"; 4. "Filhos de lavradores ou Roceiro que tenha de tres em diante, hum que não seja o mais velho, ou aquelles que constar ser mal procedido". Nestes casos, ele acrescentou, "brancos e mulatos servem". No entanto, como Viana também relatou, não havia vadios suficientes na cidade para satisfazer as exigências dos recrutamentos. Veja também Viana, "Registro do Ofício expedido ao Ministro de Estado dos Negócios Estrangeiros e da Guerra", 3 de julho de 1811, ANRJ, Códice 323 , v. 3, f57.
} 
Essas inclusões e exclusões tanto promoviam o ideal de utilidade, que era central para o ethos de um novo império no Brasil, quanto forneciam expressões de autoridade real que eram, acima de tudo, paternalistas. Era assim que Viana reclamava com o ministro Vila Nova Portugal, em 1818, que "o povo" respondia aos esforços da Coroa para impor padrões de propriedade como "Crianças, que chorão, quando seos Pais as lavão". Todavia, o intendente observou alhures que a educação moral também cultivava a deferência e o "amor" do povo ao rei, seu pai político. De fato, da mesma forma que levava as crianças a obedecerem a seus pais, ele explicava, "o premio, e o castigo dado a tempo he o unico meio que leva os homens a obrar bem e a fazer respeitar as insinuações do Soberano". ${ }^{12}$ Esta busca para conseguir alianças políticas dentro de uma estrutura de controle social atesta aquilo que o historiador António Hespanha descreve como uma mudança no entendimento dos portugueses do século XVIII sobre a natureza da ordem social, do crime e da punição. Nessa transformação, no plano dos paradigmas da ação política, a disciplina tomava o lugar do exercício simbólico da justiça como a função política que defendia a supremacia do rei. Tal mudança não era total, completa, porém, e durante os últimos anos do século XVIII e do começo do século XIX, a monarquia também continuava a fornecer justiça simbólica. De fato, em sua própria educação política, o príncipe regente D. João tinha sido aconselhado que "os Reys a terem mais do que castiguem". ${ }^{13}$ No entanto, o apoio da Coroa a um policiamento que procurasse impor a disciplina social em escalas cada vez maiores, orientado pela idéia de que, como o intendente argumentava (especialmente no caso do trabalho forçado como punição penal), o castigo iria "corrigir" o indivíduo ao qual a sentença se aplicava, sinalizava que não era apenas a presença do soberano, o embelezamento e a ampliação dos serviços e da área construída que fazia do Rio de Janeiro uma corte real. Sendo erguida em um momento de otimismo ilustrado em relação à possibilidade de reforma, a "nova Cidade" incluía a proposta de criar - com força e com educação - uma ordem sociocultural prática. ${ }^{14}$

\footnotetext{
${ }^{12}$ Viana para Vila Nova Portugal, 27 de maio, 1818, ANRJ MNB, caixa 6J 81; Viana para Aguiar, 7 de fevereiro de 1813, ANRJ MNB, caixa 6J 79.

${ }^{13}$ António Manuel Hespanha, "A punição e a graça", in Hespanha, coord. História de Portugal: O antigo regime v. 4, Lisboa, Editorial Estampa, p. 251; Francisco António de Novaes Campos, Príncipe perfeito, Emblemas de D.João de Solórzano (1790), Lisboa, Instituto de Cultura e Língua Portuguesa, 1985, f153.

${ }^{14}$ Sobre a idéia e a prática da correção na América Latina, ver Ricardo D. Salvatore e Carlos Aguirre, The Birth of the Penitentiary in Latin America: Essays on Criminology, Prison Reform, and Social Control, 1830-1940, Austin: University of Texas Press, 1996. "A tecnologia de controlar corpos e almas pela prisão, confinamento solitário e trabalho", eles explicam, "desenvolveu-se em conjunto com a doutrina que privilegiava muitas formas de punição (prisioneiros trabalhando em vias públicas) para a educação do cidadão comum”.
} 
Todavia, esses esforços de transformar o Rio de Janeiro em uma corte real, inspirados pelas experiências anteriores com a reforma urbana, a estética européia e o policiamento contemporâneo em outros contextos portugueses, não explicam completamente a natureza sem precedentes do projeto. Como capital de um "novo império florescente", conforme denominou um diplomata da época, a nova cidade do Rio de Janeiro não poderia ser simplesmente bem ordenada e refinada. Ela também tinha de exibir explicitamente o legado do "antigo sistema colonial" e a penúria que ele produziu. ${ }^{15}$ Como o médico Manuel Vieira da Silva argumentou em um dos primeiros trabalhos publicados pela Imprensa Real, a chegada da família real foi uma quebra significativa com o passado para a cidade do Rio de Janeiro e representava o começo da "feliz epocha, que faz [os habitantes da cidade] sahir da desgraça, que os rodeava, e entrar na historia das Nações policiadas". ${ }^{16}$ Ser policiado, neste sentido, era transcender o passado do colonialismo europeu e - simultânea e paradoxalmente - abraçar suas origens européias. Em outras palavras, fazer da cidade a corte significava primeiramente tirar partido de um antigo projeto imperial: civilizar o Novo Mundo.

Na transformação do Rio em uma corte metropolitana civilizada, os funcionários da corte tentaram assegurar que as "eliminações" fossem compensadas com "acréscimos" ao cenário urbano e à vida pública. Enquanto que novos palácios, prédios públicos, o teatro, academias, modas da corte e ruas iluminadas produziam o que Luccock descreveu como "a semelhança de magnificência européia”, o intendente, por seu lado, usava recursos próprios para livrar a cidade dos atributos coloniais, incluindo o uso de gelosias em prédios residenciais, característica descrita por habitantes e visitantes como gótica, deformada e pouco saudável. A retirada das gelosias, como o intendente explicou em seu edital, concorreria para o "decoro" e "perfeição" da corte, eliminando, assim, "estes testemunhos da antiga Condição de Conquista e de Colonia". ${ }^{17}$ Os cemitérios, os hospitais e as farmácias, da mesma forma, foram alvos das reformas que seguiam um "padrão euro-

\footnotetext{
${ }^{15}$ José Anselmo Correa Henriques, "Memorial sobre a residencia d'El Rey no Brasil”, BNRJ Ms. I-33,28,11, f1.Gonçalves dos Santos, Memórias, t. 1, p. 187-189.

${ }^{16}$ Manuel Vieira da Silva, Reflexões sobre alguns dos meios propostos por mais conducentes para melhorar o clima da Cidade (1808) transcrito em "Hygiene da cidade do Rio de Janeiro", ABN 1 (1876), p. 187-190.

${ }_{17}$ Viana, "Registro do Edital (...)", 11 de junho de 1809, ANRJ, Códice 323, v. 1, f88-88v; Gonçalves dos Santos, Memórias, t. 1, 237. Acerca deste projeto, ver Paulo César Garcez Marins, Através da rótula: sociedade e arquitetura urbana no Brasil, séculos XVII a XX, São Paulo, Humanitas/FFLCH/USP, 2001.
} 
peu", enquanto no teatro, como recordou Luccock, "as maneiras, os vícios, o dialeto e outras peculiaridades da colônia eram ridicularizados; e o gosto do público, por conseqüência, retificado". ${ }^{18}$ Tomadas em conjunto, essas medidas explicitamente europeizantes e metropolizantes faziam com que os funcionários da corte e os habitantes da época articulassem o significado da transferência da corte: enquanto a presença do príncipe regente e da família real minava as hierarquias políticas e culturais estabelecidas no Império, ela reproduzia as aparências e práticas européias na nova corte real e, portanto, reafirmava tanto o poder quanto a virtude que tinham motivado a expansão européia desde o princípio.

Entretanto, para os funcionários régios "civilizarem" o Rio de Janeiro, tornando-a cosmopolita, precisavam também confrontar um atributo colonial mais formidável do que as gelosias, os hospitais mal administrados e os hábitos provincianos. De fato, a diferença mais marcante entre a velha corte e a nova não era a arquitetura ou os comportamentos, mas, acima de tudo, o fato de que metade da população da nova sede imperial era composta de escravos. Afinal de contas, no mundo português da primeira parte do século XIX, a escravidão era uma prática exclusivamente colonial, já que os decretos de 1761 e de 1773 tinham estabelecido as bases para a abolição da escravatura em Portugal. ${ }^{19}$ Transformar o Rio de Janeiro numa corte cosmopolita significava romper com um passado colonial, parecia então que o uso do trabalho escravo, como as gelosias, estaria ultrapassado.

De fato, havia memorialistas e funcionários da corte que argumentavam que a escravidão representava obstáculo à prosperidade do novo império e de sua capital. Em seu tratado de como melhorar o clima do Rio de Janeiro, Vieira da Silva defendia que os escravos minavam o decoro da cidade. Muita gente, ele explicava, "chegou a possuir hum preto, ou dous, roubou-se a todo meio de industria, vive unicamente do trabalho d'quelles miseraveis, entregandose a huma vida ociosa (...) a mais carinhosa Mai dos vicios”. No entanto,

${ }^{18}$ Luccock, Notes on Rio de Janeiro, p. 245-246, 254.

${ }^{19} \mathrm{Na}$ segunda metade do século XVIII, Pombal implementou uma série de reformas no status legal de habitantes do império português. Em 1761 todos os cidadãos asiáticos da coroa portuguesa que fossem batizados como cristãos tinham garantido para si o mesmo status legal dos portugueses europeus. No mesmo ano um decreto determinava que os escravos negros que desembarcassem em Portugal seriam cidadãos livres. Em 1773 um decreto real emancipava os escravos. Como Russell-Wood observa, enquanto a emancipação das pessoas nativas foi assegurada em 1775 e 1758, o Brasil continuou sem legislação que lidasse exclusivamente com a escravidão africana. Veja A. J. R. Russell-Wood, "Iberian Expansion and the Issue of Black Slavery: Changing Portuguese Attitudes, 1440-1770", American Historical Review 83, n. 1 (February 1978), p. 40-41. 
a crítica de Vieira da Silva da escravidão era também altamente tendenciosa, pois como ele mesmo esclarecia, o verdadeiro desafio para a cortesania no Rio era a simples presença dos africanos. Portanto, de acordo com Vieira da Silva, o "interesse" do príncipe regente estava "mais no augmento dos brancos, sejão Brazileiros, ou Europeos, do que na propagação dos pretos". ${ }^{20}$ Embora Viana urgisse à Coroa que se beneficiasse de "vassalos de todos os cores", ele compartilhava esta visão e promovia ativamente a imigração dos "brancos" através de subsídios financiados pela Intendência, endossando a visão pessimista das diferenças de cor avançadas por outros conselheiros reais. Como Viana explicou para um dos juízes da cidade, "vadios brancos ou pardos, que talvez encontre nas casas de jogos", podem dar bons soldados, mas "pretos forros" deveriam ser desencorajados do serviço real. ${ }^{21}$ Essas tentativas de segregação refletiam a crença persistente da elite não apenas em relação ao limitado potencial dos africanos para adquirirem ofícios, mas também a seus temores de divisões perigosas e não produtivas dentro da população trabalhadora e da sociedade como um todo. Os senhores de escravos, explicou Vila Nova Portugal, estavam "sempre em hum estado de guerra domestica". ${ }^{22}$ Tais divisões e conflitos, ostensivamente irreconciliáveis, minavam as perspectivas de unidade no novo Império americano e em sua capital. Assim, não era somente a crítica social e econômica da escravidão como também a aceitação oficial das hierarquias de cultura e cor que pareciam anunciar o fim do trabalho africano forçado na nova corte real.

Todavia, o raciocínio das elites - tanto contra a escravidão quanto a população africana e afro-brasileira - era sobrepujado pela sua ansiedade relativa ao impacto imaginado da abolição imediata da escravatura sobre a economia e a sociedade no Brasil: o fim da agricultura de exportação e o aumento da vadiagem. Conseqüentemente, mesmo lamentando os "vícios" da escravidão, os funcionários da corte permitiram a expansão do uso do trabalho escravo. Enquanto a maior parte do crescente número de africanos trazidos à força para o porto do Rio era em seguida enviada para o Sul ou para as plantações vizinhas, muitos escravos permaneciam na cidade. Em 1818, o intendente relatou que, para atender às exigências dos "Trinta mil brancos que de pan-

\footnotetext{
${ }^{20}$ Manuel Vieira da Silva, Reflexões sobre alguns dos Meios propostos por mais conducentes para melhorar o Clima da Cidade do Rio de Janeiro, Rio de Janeiro, Impressão Régia, 1808, p. 20. ${ }^{21}$ Viana para Agostinho Petra de Bittencourt [magistrado], June 19, 1811, ANRJ, Códice 329, v. 1, f73; Viana, "Abreviada demonstração dos trabalhos da polícia" (ca.1821), RIHGB 55, pt.1 (1892), p. 378-379.

22 Vila Nova Portugal, “Sobre a questão da escravatura”, n.d. [ca.1814], BNRJ Ms. I-32,14,22, f2.
} 
cada aqui chegarão" com o príncipe regente e a família real, a população de "negros" da cidade e de seu interior tinha aumentado para algo entre 60 e 80 mil. ${ }^{23}$ Como conseqüência, remodelar o Rio de Janeiro para receber a corte traduzia a questão maior de como reconciliar a europeização da cidade com a escravidão e com os habitantes africanos e afro-brasileiros que compunham a maior parte de sua população. Em outras palavras, enquanto europeizavam e metropolizavam a cidade, os funcionários da corte tinham que dar conta do fato de que o Rio havia se transformado verdadeiramente numa cidade mais africanizada e mais escravizada.

Como uma questão de "segurança publica" e "tranquilidade", a tarefa de definir o lugar da escravidão e dos escravos na nova corte era uma preocupação de primeira ordem do intendente. Um imposto relativo aos escravos recémchegados custeava os esforços da Intendência para disponibilizar a polícia e supervisionar as pessoas cujas tarefas diárias dentro da cidade freqüentemente afastavam-nas do domínio de seus senhores. ${ }^{24}$ Seguindo a mesma lógica racista que guiava a valorização da população branca, Viana constantemente enfatizava a necessidade de ordem entre o que ele descrevia como uma população hostil, ou ao menos potencialmente desleal. "Nossa população he de pretos", ele explicou em 1816, "escravos tal vez dez vezes maior que o numero de brancos, e por isso mesmo mais facil e mais propensa a ser seduzida e que exige mais Policia". ${ }^{25}$ Dentro do Rio de Janeiro, a supervisão dos escravos em suas obrigações públicas recaía sobre a guarda da Intendência, e registros de prisão revelam quanto os escravos que viviam na cidade tinham de se submeter às suas patrulhas. Como a pesquisa de Leila Mezan Algranti revelou, uma média de $80 \%$ dos presos da Guarda e de outros membros da equipe do intendente eram escravos. Todas as apreensões restantes - com a exceção de $1 \%$ - eram de pessoas livres de cor. As razões dadas para essas detenções variavam entre roubo, perturbação da paz, posse de arma, assalto

${ }^{23}$ Viana para Sua Alteza Real, August 10, 1818, ANRJ MNB, caixa 6J 81; Luccock citado em Leila Mezan Algranti, O feitor ausente, estudos sobre a escravidão urbana, 1808-1822, Petrópolis, Rio de Janeiro, Vozes, 1988, p. 32-33. Segundo Algranti, depois de 1809, as chegadas à cidade pularam de 6.000-10.000 para 34.000, cerca de 1820. Sobre as chegadas africanas ao porto do Rio e o aumento relativo na população escrava da cidade, ver também Mary C. Karasch, Slave Life in Rio de Janeiro, 1808-1850, Princeton, Princeton University Press, 1987, p. 61-62; e Manolo Garcia Florentino, Em costas negras, uma história do tráfico Atlântico de escravos entre a África e o Rio de Janeiro (séculos XVIII e XIX), Rio de Janeiro, Arquivo Nacional, 1995, p. 59.

${ }^{24}$ Viana para Aguiar, July 1, 1809, ANRJ MNB, caixa 6J 78. O imposto era de 800 réis para cada "novo escravo" e $4 \$ 800$ réis para aqueles que fossem enviados para as regiões do Sul. ${ }^{25}$ Viana [representação], 24 de novembro de 1816, ANRJ MNB, caixa 6J 83. 
e homicídio, fuga e capoeira, arte marcial afro-brasileira, que os senhores de escravos e os funcionários da Coroa associavam intimamente com a atitude de desobediência violenta. ${ }^{26}$ As prisões, no entanto, não representavam a totalidade das atividades da Guarda. Como o próprio intendente reconhecia, muitos confrontos entre os membros da Guarda e as pessoas de cor não tinham mandato e não eram registrados. De fato, em 1811, ao punir o comandante da Guarda pelo espancamento gratuito de negras quitandeiras na rua, Viana acabou lembrando a seu subordinado que a "Guarda da Policia deve evitar desordens e não suscitá-las". ${ }^{27}$

Quando a Guarda formalmente prendia um escravo, em muitos casos as conseqüências eram a punição sumária com uma sentença de açoites, serviço forçado nas galés, ou ambos, enquanto as sentenças para as pessoas livres eram principalmente limitadas a trabalho forçado e, em alguns casos, desterro. Como Viana explicou em um relatório, justificando a prisão e o trabalho forçado de um "crioulo Francez" de nome João Baptista, aqueles acusados do que se chamavam "pequenas desordems", na falta de evidência necessária para prosseguir com a acusação, eram postos a trabalhar na construção de estradas na região. Depois de 1814, segundo Algranti, a Intendência também passou a prender escravos. De fato, enquanto ao longo do período em que o calabouço (uma cadeia localizada na área da cidade conhecida como Castelo) manteve presos vadios livres, bem como desertores, essa cadeia veio a ser associada quase exclusivamente aos "castigos de correção tão necessário aos escravos". 28 O encarceramento, no entanto, não excluía o trabalho em obras públicas. De fato, depois da transferência da corte, a Intendência se envolveu em numerosos grandes projetos para melhorar a infra-estrutura da cidade. Neste contexto, a população presidiária de escravos e pessoas livres tornou-se, na verdade, a primeira fonte de trabalho da Intendência, e a extensão das "correições" foi ajustada de acordo com as necessidades do intendente. ${ }^{29}$

\footnotetext{
${ }^{26}$ Algranti, op. cit., p. 189, 209.

${ }^{27}$ Viana para Tenente Coronel José Maria Rebello, Comandante da Guarda Real da Polícia, 17 de janeiro de 1811, ANRJ Antiga Seção Histórica, caixa 1227, pacotilha 1. Ver também Viana, "Registro do Officio expedido ao General das Tropas", 1 de abril de 1809, ANRJ, Códice 323 , v. 1 , no qual ele adverte o guarda por deixar de seguir o procedimento na prisão de dois pardos.

${ }_{28}$ Algranti, op. cit., p. 194; Viana, "Registro do Ofício Expedido ao Ministro de Estado dos Negócios Estrangeiros", January 24, 1817, Códice 323, v. 4; Viana, "Registro do Ofício Expedido ao Juiz de Crime do Bairro de Santa Rita", May 19, 1817, Códice 329, v. 4, f17v; e Viana para Aguiar, 25 de fevereiro de 1813, ANRJ MNB, caixa 6J 79.

${ }^{29} \mathrm{O}$ uso de presidiários em trabalhos públicos foi uma prática que se intensificou nos últimos anos do século XVIII no Brasil devido à expansão dos serviços urbanos. Ver Patricia Ann Aufderheide, "Order and Violence: Social Deviance and Social Control in Brazil, 1780-1840", Tese de doutoramento, University of Minnesota, 1976, p. 302-303. Sobre as formas de trabalho na prisão Karasch, p. 118-121. Encher as prisões para ter força de trabalho foi criticado em 1822 pelo sucessor de Viana. Ver Algranti, op. cit., p. 81.
} 
Em alguns casos, condenar um escravo a trabalhar para a Intendência por uma infração pública colocava o intendente em má situação em relação ao senhor do escravo, que até então contava com o acesso exclusivo a seu trabalho. Por outro lado, a Intendência também desempenhava um papel importante no que dizia respeito ao controle da população de escravos, sendo responsável pela implementação de punições a pedido dos senhores. Nesses casos, os escravos eram depositados no calabouço e depois postos em um grupo de trabalho forçado ou açoitados, sendo que os senhores compensavam a Intendência com o pagamento de 160 reis por cada cem chibatadas. Como Algranti observou, esta intervenção no âmbito quase privativo das relações entre escravos e senhores de escravos distinguia a experiência dos escravos na cidade daqueles que viviam em ambientes rurais, onde as punições eram tipicamente administradas em nome do senhor por um feitor. ${ }^{30}$

No entanto, ao mesmo tempo que a prática de oficialmente dar punição em nome dos senhores de escravos reafirmasse o apoio da Coroa a estes, ela também dava à Coroa e à Intendência maior número de oportunidades para definir as características da escravidão na cidade. Situação descrita por Vieira como sendo a necessidade de confirmar a "segurança que os Senhores tem de que o Estado lhes assegura sempre o castigo dos escravos", algo definido e limitado pelo desejo da Coroa em manter a ordem. Assim, embora as condenações do castigo físico aparentemente se tornassem mais severas após 1815, com escravos sendo condenados a até 300 chibatadas, Viana também desencorajou a punição excessiva e, em alguns casos, recusou-se a administrar o número de chibatadas solicitado pelo senhor, quando ele julgava que isso geraria maiores distúrbios.

De fato, embora Viana mantivesse a ameaça de punição extrema e pena de morte, ele também questionou a conveniência da punição pública em geral. Em 1818, Viana afirmou que ele sempre tinha temido punir "pretos e gente rude (...) fora da Casa para isso destinada (...) porque andalos a açoitar pelas ruas e nos lugares dos delitos seria desafiar motins". ${ }^{31}$ Com efeito, embora aparentemente não houvesse padrões rigorosos estabelecidos para a punição dos escra-

\footnotetext{
${ }^{30}$ Algranti, op. cit., p. 51, 198; Karasch, op. cit., p. 122-124; Aufderheide, op. cit., p. 93. A prática, na verdade, antecipou a incorporação total da punição dos escravos na esfera pública no final dos anos 20, na década de 30 do século XIX. Assim, as tentativas de controlar a população de escravos no Rio contrastou fortemente com os esforços feitos no interior e em pequenas cidades e vilas, onde as recapturas dos escravos que fugiam eram de responsabilidade do capitão do mato.

${ }^{31}$ Viana para Sua Alteza Real, 10 de agosto de 1818, ANRJ MNB, caixa 6J 91; Algranti, op. cit., 193, p. 197.
} 


\section{Perfeita civilização: a transferência da corte, a escravidão e o desejo} de metropolizar uma capital colonial. Rio de Janeiro, 1808-1821

vos, como um juiz relatou por volta de 1817, "não esteja em uso pratico [estes] serem açoutados no Pelourinho e Praça do Rocio" ou em outras praças públicas. Enquanto esse juiz observou que os homens livres eram açoitados em praça pública, os escravos eram açoitados na prisão. Esse mesmo juiz, no entanto, pediu uma exceção, esperando dar um "exemplo aterrador" de dois escravos praticantes de capoeira. O pedido foi provavelmente negado, pois somente um ano mais tarde, quando outro juiz decidiu punir um escravo com açoitamento público no pelourinho, a punição foi suspensa e os funcionários que aplicavam as chibatadas foram detidos. Enquanto o juiz pedia esclarecimento sobre a maneira apropriada de proceder, ele mesmo reconhecia o pelourinho como o lugar "onde os reos brancos se levão a açoutar nas costas". ${ }^{32}$ Viana considerava essa restrição da punição pública dos escravos como um gesto que atenuava a corrupção chocante que (como muitos argumentavam) era encorajada pela presença de uma grande população de escravos. ${ }^{33}$ Era "verdadeiramente indecente dentro de hum corte", ele insistia, "que se tem os açoites em publico nas Praças pelo modo que no Brasil se castigão os escravos". ${ }^{34}$

No entanto, a punição não era a única característica chocante ou problemática da escravidão na cidade. De fato, para muitos funcionários da corte, suas conseqüências piores eram associadas à chegada dos africanos ao Brasil

\footnotetext{
32 António Felipe Soares de Andrada de Brederode, Corregedor da corte e Casa, 27 de fevereiro de 1817, ANRJ, Casa da Suplicação, caixa 1707, antiga caixa 774, pacotilha 3; José Albano Fragoso, Corregedor do Crime da corte e Casa, Abril 4, 1818, ANRJ, Casa da Suplicação, caixa 1707 , antiga 774 , pacotilha 4 . Nem todos os magistrados eram tão resolutos quanto Viana, na questão da punição pública, e os debates sobre a punição dos escravos continuou. De acordo com Debret, que deu descrições tanto visuais como textuais do açoite público dos escravos, essas práticas foram "restabelecidas com todo o rigor" e interrompidas mais uma vez em 1829, embora alguns escravos criminosos e capoeiras ainda tenham sido punidos dessa maneira em público. Ver sua Viagem, t. 2, p. 175-177, e prancha 45; e Karasch, op. cit., p. 122-125. Legalmente, o açoite era uma pena vil, e um certo número de exceções relacionadas ao cargo e status foi estipuplado que não se aplicava no caso de certos crimes de Lesa-Majestade, sodomia, feitiçaria, levantando falso testemunho, e falsificação. No Império do Brasil independente, a prática do açoite foi interrompida, exceto no Exército e na Marinha e no caso dos escravos. Ver Ordenações Filipinas (1603), Livro V, Título 138. Esforços para restringir a punição excessiva dos escravos continuaram durante o século $\mathrm{XIX}$, mesmo que, em alguns casos, os tribunais dispensassem sentenças severas que pareciam contradizer essas convenções. Ver Alexandra Kelly Brown, "'On the Vanguard of Civilization': Slavery, the Police, and Conflicts between Public and Private Power in Salvador da Bahia, Brazil, 1835-1888", Tese de doutoramento, University of Texas at Austin, 1998. Segundo Brown, o fim do açoite público também marcou "uma transição para uma nova era na qual o desconforto popular com espetáculos públicos de violência esteve por de trás da emergência das prisões como depósitos de castigo legalmente determinado".

${ }^{33}$ Marquês de Borba para a Condessa do Redondo [sua nora], Rio de Janeiro, 20 de fevereiro, 1809, em Pereira, Filhos, p. 140.

${ }^{34}$ Viana para Sua Alteza Real, 10 de agosto de 1818, ANRJ MNB, caixa 6J 81.
} 
e sua venda subseqüente. "Os pretos desembarcão, e são logo expostos a venda", o médico Vieira da Silva reclamava em 1808, "entrão nas differentes cazas, e permitte-se lhes a livre communição com a gente dellas, particularmente as crianças, porque não ha outras pessoas, a quem se entregue o seu cuidado". ${ }^{35}$ Para melhorar essas condições, os funcionários tentaram estabelecer novos padrões de higiene para o mercado de escravos do Valongo. Embora os comerciantes de escravos reclamassem das taxas cobradas, depois de 1810, os donos dos depósitos comerciais intermediários, perto do Valongo, foram incumbidos de preparar os escravos para a venda, incluindo quarentena e vestimentas, enquanto que Viana estabeleceu padrões para enterros mais ordenados e higiênicos no "cemiterio dos negros novos" nas vizinhanças do mercado. ${ }^{36}$ Os esforços para mitigar essa situação, que os funcionários da corte identificavam como oriundas da "indecência" da escravidão, também incluíram as tentativas, em última instância fúteis, de esconder a mãode-obra escrava por parte dos senhores de escravos, enquanto os senhores continuavam a depender dos escravos, tanto no comércio, quanto em casa. Alguns visitantes que passavam pela cidade comentaram acerca da moda de se substituir o trabalhador africano e afro-brasileiro pelo trabalhador europeu em certas profissões. Como o britânico Ellis relatou, enquanto "os mecânicos eram anteriormente todos mulatos", em 1816, "os residentes da corte (...) encorajavam não somente os portugueses mas os europeus a se estabelecerem como artífices". ${ }^{37} \mathrm{O}$ habitante britânico Luccock também notou a preferência pela mão-de-obra européia, especialmente como um meio de refletir status. Em cortejos formais, ele explicou, as carruagens eram "puxadas por cavalos, ao invés de mulas e acompanhadas por empregados brancos, ao invés de escravos". Aparentemente, outros senhores de escravos, reconhecendo que o uso do trabalho escravo não podia ser escondido, deram mais consideração à aparência dos próprios escravos. Como Luccock explicou mais adiante, enquanto, após a chegada da corte, "empregados de cor branca eram mais geralmente vistos, (...) os escravos para ocupações domésticas, embora menos numerosos, eram mais

\footnotetext{
${ }^{35}$ Reflexões, p. 18-19.

${ }^{36}$ Noronha Santos, "Anotações de Noronha Santos", em Gonçalves dos Santos, Memórias, t. 1, 104; "Representação de Negociantes d'esta corte abaixo assignados, proprietarios, consignatarios, e Armadores de resgate de escravos", n.d. [post 1810-16], BNRJ Ms. II-34,26,19, f1; Viana para Juizes do Crime do Bairro de São José, Santa Rita, Candelaria e Se, 15 de fevereiro de 1811, ANRJ, Códice 329, v. 1, f10.

${ }^{37}$ Henry Ellis, Journal of the Proceedings of the Late Embassy to China (...) (1817), Wilmington, Scholarly Resources, 1973, p. 11.
} 
cuidadosamente escolhidos e recebiam melhores roupas e alimentação". ${ }^{38}$ No entanto, como Silvia Lara explicou, essa preocupação com a vestimenta e aparência dos escravos antecedeu a chegada da corte. Podemos encontrála, por exemplo, em expressões de ostentação senhorial atribuída à noção de que, como um crítico do século XVIII da escravidão comentou, "o corpo de um escravo ou empregado doméstico é como uma parte do corpo do seu senhor". ${ }^{39}$ Depois da transferência da corte, as dimensões dessa ostentação cresceram à medida que as elites da cidade usaram os escravos e os séquitos de escravos, juntamente com as carruagens e a roupa, para projetar sua aparência nobre [cortesã? ]. Enquanto a intervenção real em relação à punição e venda de escravos e o fingimento de refinamento da elite tentavam ocultar e higienizar a brutalidade da escravidão e, assim, criar uma aparência de corte metropolitana, tais medidas eram também vistas como dando a base para um controle mais efetivo da população escrava. Elas se baseavam na noção de que a ordem tinha dimensões tanto morais com físicas, ou, como Viana defendia, que "a força moral pode sempre mais que a força fizica". De fato, neste sentido, o tratamento inicial dos escravos no Valongo marcou, idealmente, o começo da imersão dos mesmos na sociedade européia, sob a égide da autoridade patriarcal de seus senhores. Essa passagem era considerada por Viana e outros membros da elite a saída da vida selvagem africana, caracterizada por nudez e violência. Punição medida, ao invés de excessiva, por sua vez, iniciou, de modo ostensivo, os escravos nos hábitos da justiça européia. ${ }^{40}$

No entanto, o intendente também demonstrou preocupação de que esses ideais paternais e morais tivessem sido esquecidos na nova corte real. Viana denunciou que os donos que davam importância à aparência de seus escravos eram em menor número do que os que os deixavam "descalsos e malvestidos", bem como ignorantes da "immortalidade d'alma e dua hua vida eternal". Como conseqüência disso, afirmou Viana, os escravos ficavam rancorosos, cheios de ódio e desobedientes. Nessas circunstâncias, a punição só podia levar a mais conflito e desordem. Como essa crítica lembrava denúncias anteriores dos senhores de escravos, feitas antes da transferência da corte, Viana de fato atribuiu a falta de cuidado com o bem-estar dos escravos ao uso ampliado do trabalho

\footnotetext{
${ }^{38}$ Luccock, Notes on Rio de Janeiro, p. 245, 548.

${ }^{39}$ Manuel Ribeiro Rocha, Etíope Resgatado (1758), citado em Silvia Hunold Lara, "Signs of Color: Women's Dress and Racial Relations in Salvador and Rio de Janeiro, ca.1750-1815", Colonial Latin American Review 6, n. 2 (1997), p. 214.

${ }^{40}$ Para uma explicação contrastante da relação entre disciplina, punição e escravidão, ver Brown, "On the Vanguard", p. 197.
} 
escravo na cidade após 1808. "Com a vinda da corte para este Cidade", ele explicou, "veio nos o grande bem de se aumentar consideravelmente a povoação della" e muitos destes recém-chegados à cidade, por sua vez, adquiriram escravos "ao modo do Pais, por haver dificuldade de achar brancos, como em Portugal, por os seus serviços”. Esses novos senhores, continuou o intendente, "querendo ganhar a sua vida, a dar giro as suas fortunas, aproveitando-se do meio de comprar escravos para os trazerem a jornaes nas obras publicas, nas Alfandegas, e no Serviço da Cidade". Como esta prática de alugar escravos por dinheiro era teoricamente sensata, Viana observou que, na prática, "o desejo de tirar logo lucro" dos escravos recém-chegados significava que esses novos senhores tanto falharam em dar instrução religiosa a seus escravos, como também os haviam tratado indevidamente. Como resultado disso, Viana lamentou o fato de que o "antigo equilibrio" havia se perdido". ${ }^{41}$

Dessa forma, a transformação do Rio de Janeiro na corte do Novo Mundo resultou em abordagens profundamente contraditórias com relação à escravidão. De um lado, os habitantes da cidade, os exilados do reino e os funcionários da corte, conjuntamente, procuraram exercer a prática de uma escravidão "decorosa". De outro, como o intendente observou, à medida que a busca de prosperidade no Novo Mundo resultou no crescimento da população escrava, o processo de metropolização foi minado. $O$ ideal de civilização incorporado na moralidade, educação e boas maneiras que a nova corte deveria demonstrar e que, como Viana nostalgicamente afirmou, tinha sido alimentado antes da chegada de D. João, foi rompido. Como um "filho deste Pais", Viana lembrava como os "senhores que chamavão a sua casa brancos e pretos que viviam de ensinar a doutrina [religiosa] a escravatura". Infelizmente, disparou ele, os recém-chegados ao exílio na cidade não conseguiram apreciar essa dimensão paternal de posse. ${ }^{42}$

Como uma solução de curto prazo para este problema, Viana propôs que a intendência, a igreja e os tribunais assumissem um papel mais ativo para assegurar que os senhores de escravos dessem a estes uma "educação moral". Tal educação atestava tanto as continuidades entre o policiamento e a disciplina das classes populares livres e escravizadas da cidade, quanto a natureza

\footnotetext{
${ }^{41}$ Viana para Sua Alteza Real, 10 de agosto de 1818, ANRJ MNB, caixa 6J 81. Para denúncias anteriores das falhas dos senhores de escravos, ver Ronaldo Vainfas, Ideologia e escravidão: os letrados e a sociedade escravista no Brasil Colonial, Petrópolis, Vozes, 1986. Sobre a prática de usar escravos como trabalhadores assalariados, traficantes e fornecedores de outros serviços pagos, ver Karasch, op. cit., capítulo 7.

${ }^{42}$ Viana para Sua Alteza Real, 10 de agosto de 1818.
} 
dessa disciplina dentro do Império. Da mesma forma que os membros da corte ensinavam às elites da cidade a serem "metropolitanas", os habitantes e funcionários da cidade ensinavam aos membros da corte a serem, de fato, "coloniais": ou seja, a reconhecerem os meios de preservar a ordem e a civilidade, dentro da prática brutal da escravidão. Como Viana observou, descrevendo a disposição local, "quem vive neste Pais assustase menos destes negócios". Em outras palavras, e como mesmo Viana chegou a reconhecer, constituir a cidade metropolitana do Rio exigia a tolerância para com as velhas práticas não metropolitanas. Assim, como os membros da corte se reservavam o direito de perseguir os africanos e os afro-brasileiros nas ruas do Rio, eles admitiam que, enquanto o Brasil mantivesse a instituição da escravidão, a mera presença pública dos escravos, suas reuniões e suas formas de vida, eram fatos sociais e políticos, bem como econômicos. Como o ministro da coroa Marquês de Aguiar admitiu ao conde dos Arcos, não somente era "impossível” proibir reuniões de escravos, "que são os braços, de que todas as familias se servem no Brazil, conduzão seus Senhores aos Templos, ao Theatro vão buscar agoa nas fontes, e fação outros serviços desta natureza (...)", como também o fato da natureza dessas atividades significava que as reuniões de escravos deveriam ser aceitas como "inevitável, ainda que daqui possa acontecer alguma desordem (...)". ${ }^{43}$ A nova cidade e corte do Rio de Janeiro no Novo Mundo era, dessa maneira, um lugar onde, desde que os escravos não participassem de má conduta em grande escala, as irmandades africanas e afro-brasileiras se reunissem no Campo de Santana aos domingos e outros dias festivos, assegurando um processo de contribuições financeiras para suas atividades. Também era um lugar onde, tendo obtido a licença apropriada do intendente, as comunidades africanas da cidade e regiões vizinhas podiam decidir e celebrar suas hierarquias locais. ${ }^{44}$ Estas características da vida cotidiana no

\footnotetext{
${ }^{43}$ Aguiar para conde dos Arcos, 6 de junho de 1814, BNRJ Ms. 33,34,29. João José Reis descreve essas permissões, que Arcos defendeu ferrenhamente, como "controle ilustrado dos escravos". Ele objetivava tanto "atenuar o excesso dos senhores", ele explica, como dividir, e, portanto, conquistar, a população africana, dando-lhes "livre expressão das tradições africanas" e, assim, afirmava Arcos, exacerbando as diferenças étnicas. Os efeitos reais não foram tão evidentes. Como observado pela correspondência entre Aguiar e Arcos, os escravos na Bahia continuaram a se rebelar, enquanto os senhores e os funcionários da corte no Rio foram poupados. Ver Reis, Slave Rebellion in Brasil, The Muslim Uprising of 1835 in Bahia, Baltimore, Johns Hopkins University Press, 1993, p. 44-53.

${ }^{44}$ Viana para Aguiar, 20 de abril de 1813, ANRJ MNB, caixa 6J 79; "Registro do Ofício expedido ao Juiz do Crime do Bairro de São José”, 15 de outubro de 1813, ANRJ, Códice 329, v. 2, f1.22v; Leila Mezan Algranti, "Costumes Afro-Brasileiros no corte do Rio de Janeiro: Um Documento Curioso", Boletim do Centro de Memória UNICAMP 1, n. 1 (jan.-jun. 1989), p. 17-21; Silvia Hunold Lara, "Significados Cruzados: As Embaixadas de Congos no Brasil Colonial", in Maria Clementina Pereira Cunha (ed.), Carnavais e outras f(r)estas: ensaios de história social da cultura (Campinas, 2002), p. 71-100.
} 
Rio distinguiam a nova corte da antiga, na qual a população africana era relativamente menor e um traço menos marcante da vida pública. Apesar disso, as reuniões sociais ordeiras de africanos e afro-brasileiros também podiam ser interpretadas como algo que assegurava a continuidade entre um passado colonial e um futuro imperial. Afinal de contas, como observou uma ordem real, "em todas as Cidades policiadas do Mundo se permittem divertimentos públicos proporcionados até as últimas classes da Nação". ${ }^{45} \mathrm{O}$ policiamento dos escravos, neste sentido, se aproximava do policiamento das classes livres mais baixas. Em ambos os casos, como Viana repetidamente afirmava, se tratava de assegurar a manutenção da ordem, da hierarquia e da autoridade real.

Essas percepções contemporâneas da necessidade urgente de se policiarem e controlarem os escravos com repressão física e disciplina social foram também formadas pela consciência de um cenário político em mutação, que agora incluía explicitamente os próprios escravos. A escolha que se apresentava aos habitantes do Brasil, como explicou um funcionário da Coroa, era entre "aquelle antigo respeito, que os homens de cor pardo, ou preto prestavão a classe dos brancos" e "aquella perigoza maxima de igualdade com que os freneticos filosofos buscão anniquilar totalmente as Sociedades Civilizadas". ${ }^{46}$ Logicamente, quer ou não os escravos expressassem suas aspirações políticas em termos das agendas liberais propostas em outras partes do Atlântico, a brutalidade, a falta de humanidade e a ausência de civilização inerentes à escravidão sempre apontavam para a insurreição como uma possibilidade concreta. As lutas entre as potências européias abriam oportunidades para revoltas e insurreição, em particular, em termos do exemplo formidável do potencial de protesto colonial dentro da crise européia. Tanto escravos quanto senhores percebiam esse elemento e, em 1814, os senhores de escravos no Brasil informavam aos funcionários da Coroa que seus cativos "falão, e sabem do sucesso fatal da Ilha de São Domingos". ${ }^{47}$

Os estadistas imperiais e os funcionários da Coroa no Brasil preocupavam-se com a inspiração que a Revolução do Haiti poderia provocar nas pessoas de cor na colônia antes da transferência da corte. Porém, na segunda

45 "[Cópia do Ordem do Dia]", 10 de abril de 1814, BNRJ Ms. II 34,6,57. Esta ordem proibia certas formas de dança de batuque, mas permitia outras reuniões africanas e afro-brasileiras e foi vigorosamente contestada por senhores baianos.

${ }^{46}$ Vicente António de Oliveira, "Reflexões sobre a instituição das Forças Armadas da Capitania do Rio de Janeiro", 15 de fevereiro de 1816, BNRJ Ms. I-33,50,35.

47 "Representação do Corpo do Comércio e mais Cidadões da Praça da Bahia", [1814], BNRJ Ms. II-34,6,57. 
década do século XIX a questão, como um estadista a formulou, de como evitar "o perigo de reação das raças" que tinha devastado e continuava a devastar “as desgraçadas Antilhas" revestiu-se de uma nova urgência. De um lado, aquilo que o economista político José da Silva Lisboa descrevera como "o horrido espectaculo da tremenda catastrophe da Rainha das Antilhas, transformada em Madagascar" poderia ser visto como uma história que reforçava os argumentos a favor da necessidade de se substituírem as pessoas de cor e a população escrava (ostensivamente não produtiva e hostil) por imigrantes europeus no novo império americano e corte real do Rio de Janeiro. ${ }^{48}$ De outro, o intendente Viana via o exemplo do Haiti e sua possível influência nos escravos no Brasil como uma questão mais imediata de segurança. Como a rebelião era, logicamente, intolerável em qualquer época e em qualquer lugar no Brasil, a guerra na Europa, Viana argumentou, representava um perigo maior ainda. O Brasil supostamente representava um ponto fraco na oposição política e cultural frente a Napoleão em termos de sua população escrava. Escrevendo em 1808, Viana afirmava que uma rebelião de escravos na nova corte do príncipe regente certamente encorajaria os "bem conhecidos inimigos" da monarquia portuguesa. Mesmo depois do final da guerra, em 1816, Viana insistia que "tendo sabido, e de certo com exageração, que tem havido espirito insubordinado na escravatura da Bahia", os defensores de Napoleão acreditavam que "por ahi possão ser mais bem recibidos". ${ }^{49}$

Para Viana e outros conselheiros reais, a solução era a revista e detenção de qualquer indivíduo, branco ou preto, que fosse visto como tendo conexões com o Caribe, bem como (não surpreendentemente) aqueles que expressassem agendas abolicionistas. Assim, em 1816, "hum preto de nome de Carlos Romão que he de Nação Franceza" viu-se na cadeia da cidade, para que o intendente pudesse determinar se ele era "da Ilha de São Domingos, ou dali viesse (...)

${ }^{48}$ Sobre o espectro do Haiti, ver F. G. Cailhé, "Projet" e "Memoire et Notes Explicatives Sur Le Projet", Rio de Janeiro, 15 de dezembro de 1820, BNRJ Ms. I-33,29,8 e I-33,29,16; Silvestre Pinheiro Ferreira, "Memórias Políticas sobre os Abusos Gerais e Modo de os Reformar e Prevenir a Revolução Popular Redigidas por Ordem do Principe Regente no Rio de Janeiro em 1814 e 1815”, in Idéias políticas, Rio de Janeiro, Editora Documentário, 1976, p. 31; João Severiano Maciel da Costa, Memória sobre a necessidade de abolir a introdução dos escravos africanos no Brasil (...), Coimbra, 1821, em Graça Salgado, ed., Memórias sobre a escravidão, Rio de Janeiro, Arquivo Nacional, 1988, e José da Silva Lisboa, Memoria dos beneficios politicos do governo de El-Rey Nosso Senhor D.João VI, Rio de Janeiro, Impressão Régia, 1818, p. 160 (grifado no original).

${ }^{49}$ Viana, "Registro do Ofício expedido ao Ministro e Secretário da repartição da Guerra", 23 de maio de 1808, ANRJ, Códice 318, f16-16v; Viana, [representação para D. João], 24 de novembro de 1816, ANRJ MNB, caixa 6J 83. 
se ha outros, ou mulatos, se ja esteve na Bahia, ou conhece alguns que la estejão e viessem de São Domingos, e signaes por onde se possão descobrir”. Essas ações, no entanto, também envolviam riscos. Como Viana comentou acerca da detenção de três "pretos de Martinica", àquele que podia verificar suas ocupações passadas e presentes, "destes mesmos sempre tenho procurado não entrar com elles em exames judiciaes nem com inquirições de testemunhas que sempre vão dar Corpo que a couzas não tem, e suscitar ideas, athe ignoradas da maior parte das gentes". ${ }^{50}$ Sendo assim, escravos e pessoas de cor eram suspeitas de promover a insurreição e simultaneamente consideradas como inconscientes das políticas de contestação. As afirmações dos senhores de que os escravos eram de uma condição "tão barbara" que "não temem morrer" sugeriu limites à organização ideologicamente motivada, reassegurando aos funcionários da corte e aos senhores que certas idéias revolucionárias permaneceriam, nas palavras de Viana, "ignoradas". Contudo, as idéias de liberdade e igualdade eram também percebidas como sendo contagiantes. Suas conseqüências potenciais pareciam tão inevitáveis precisamente porque os senhores e os funcionários régios reconheciam o apelo em potencial dessas idéias em relação às pessoas que não tinham motivo para preservar desigualdades, a falta de liberdade e as hierarquias que serviam somente para oprimi-los. A escolha da coroa em manter a instituição da escravidão no Brasil e em sua nova corte americana significava, portanto, que as experiências de policiar, governar e morar na cidade, bem como a transformação dessa em uma metrópole, seriam moldadas por uma sensibilidade colonial de vulnerabilidade e a política de medo por parte da elite colonial.

O projeto de fazer do Rio de Janeiro a capital do Império era uma busca de tornar a cidade não somente esplendorosa, mas também ordenada, moralizada e decorosa. Tornando-se a corte real, neste sentido, fez-se com que a cidade se tornasse "policiada". O policiamento, por sua vez, significou não somente garantir a "segurança pública", mas também fazer do Rio uma metrópole, reconhecendo a diferença entre a metrópole e a colônia, justamente para que essas diferenças pudessem ser diminuídas. Tal projeto era sustentado pela concepção de "civilização" ilustrada da Europa do século XVIII e sua missão disciplinadora. Contudo, ao mesmo tempo em que os funcionários da corte procuravam erradicar as "indecências" da colônia, esses também man-

${ }^{50}$ Viana, "Registro do Ofício expedido ao Juiz do Crime do Bairro de Santa Rita", 11 de abril de 1816, ANRJ, Códice 329, v. 3; Viana, Registro do Ofício expedido ao Ministro de Estado dos Negócios de Guerra”, 8 de julho de 1808, Códice 318, f38. 
tinham uma instituição colonial preeminente: a escravidão africana. Desse modo, enquanto "aperfeiçoar" o Rio implicava embelezar a cidade e melhorar sua infra-estrutura cultural e econômica, "havendo se elevado esta Cidade a alta hierarquia de ser hoje corte do Brasil", também significava produzir o que Stoler e Cooper associaram com "a tensão mais básica do império": a busca inevitável para definir o status da diferença no meio de uma "alteridade" contingente e instável. ${ }^{51} \mathrm{~A}$ escravidão, assim imaginava o intendente e outros funcionários régios, seria elegante e cosmopolita se os escravos fossem moralmente educados e se sua presença na cidade fosse cuidadosamente controlada. Não obstante o fim do velho sistema colonial, no caso da escravidão, foi uma intensificação do colonialismo que tornou a "nova Cidade" do Rio de Janeiro imperial.

\footnotetext{
${ }^{51}$ Ann Laura Stoler e Frederick Cooper, "Between Metropole and Colony, Rethinking a Research Agenda”, in Stoler e Cooper, eds., Tensions of Empire: Colonial Cultures in a Bourgeois World, Berkeley, University of California Press, 1997, p. 7.
} 